\title{
Legal Aspects of Doing Business in Kenya - An Outline for German Companies
}

\author{
Jörg Kleis*
}

\begin{abstract}
The Kenyan market is one example of business opportunities in Africa. Kenya shows notable improvements in terms of business-related reforms while being in continuous need of investments in the energy and infrastructural sector. Still, many European companies and investors, particularly the German Mittelstand, are reluctant when it comes to implementing a project. Doing the math is not as much of a problem. Instead, there remain several unanswered, but essential legal questions. In the case of Kenya they concern investment conditions, competences, procedures and pertinent material regulations to finally engage in doing business.
\end{abstract}

\section{A. Introduction}

Kenya is Africa's fourth-largest economy after Nigeria, South Africa and Angola and the vastest market in East Africa. Kenya exceeds other East African Community (EAC) partner states $^{1}$ in terms of market size and substance. The country is drawing much attention, not only because it was able to triple its gross national income per capita over the past ten years, making it a (lower) middle income country. Even the media have found delight in regularly portraying Nairobi's innovative start-up scene. Kenya is currently among the top ten performers worldwide showing the most notable improvement in terms of business-related reforms. ${ }^{2}$ The government passed legislation to reduce the time to assess and pay stamp duty and to make property transfers faster through electronic document management.

* Rechtsanwalt Jörg Kleis is the founder of Jenga Legal (www.jenga-legal.de), a law firm based in Berlin (Germany) advising clients on market entry, business implementation and problem-solving in African countries, one of which is Kenya. His focus on Africa began in 2009 when he worked as a research fellow at Freie Universität Berlin. Later he became a scholar with the Friedrich Naumann Foundation and wrote his dissertation on the contribution of African Community Courts to continental integration. During his legal training he worked at the Department for Sub-Saharan Africa of the Federal Ministry of Economics and for Deutsche Entwicklungs- und Investitionsgesellschaft $\mathrm{mbH}(\mathrm{DEG})$ in Cologne (Germany).

1 The partner states of the EAC are Burundi, Kenya, Rwanda, Tanzania and Uganda. Integration efforts are concentrated on putting the theoretical framework of the 2010 East African Common Market Protocol into practice.

2 World Bank Group, Doing Business Report 2016. Measuring Regulatory Quality and Efficiency, p. 11, http://www.doingbusiness.org/ /media/GIAWB/Doing\%20Business/Documents/Annual-Report s/English/DB16-Full-Report.pdf, accessed on 8 February 2016. 
It enabled access to positive credit information and expanded borrower coverage. Delays for new electricity connections were reduced by enforcing service delivery timelines and hiring contractors for meter installation. ${ }^{3}$ On the other hand, Kenya made dealing with construction permits more difficult by requiring an additional approval before issuance of the building permit and by increasing the costs for both water and sewage connections. In any case, such efforts underline the goal of remaining an attractive destination for foreign entrepreneurs and investors. However, besides dealing with the fiscal side to successfully implementing a project they need to take the (inter)national legal framework into account.

\section{B. International legal framework}

\section{Law of the World Trade Organization}

Both being members of the World Trade Organization (WTO), Kenya and Germany are bound by the trade-related agreements stipulated under the annexes to the Agreement establishing the WTO. ${ }^{4}$ The well-known most favoured nation clause in the General Agreement on Tariffs and Trade (GATT) ensures equal trade advantages for German companies, for example low tariffs or higher import quotas, as they are provided to companies from another nation most favoured by Kenya. ${ }^{5}$ The same accounts for the national treatment clause, prohibiting internal taxes or charges on imported German products in excess of those applied to like domestic (Kenyan) products. ${ }^{6}$ The General Agreement on Trade in Services (GATS) extends the most favoured nation principle and thus the protection through equal treatment unconditionally to German services and service providers. ${ }^{7}$ It also means that the Kenyan market for public procurements, such as projects for road construction, is open to German suppliers. They must not be ousted from a tendering process through the modification of conditions in favour of Kenyan service suppliers. ${ }^{8}$ Last, the Agreement on Trade-Related Investment Measures (TRIMs) enables German companies to operate more easily in Kenya

3 Ibid, pp. 50 and 175. According to the Report, Kenya ranks 9 out of 47 in Sub-Saharan Africa and 3 out of 47 when it comes to getting credit.

4 While their applicability naturally depends on the type of business or investment, the GATT, GATS and TRIMs shall be considered the most pertinent ones in this context. Their legal content partially overlaps and is thereby reinforced. There exist several other agreements that may be applicable, such as the Agreement on the Rules of Origin, the Agreement on Trade-Related Aspects of Intellectual Property Rights, the Agreement on Technical Barriers to Trade or the Agreement on Import Licensing Procedures.

5 Article 1(1) GATT; Peter Neumann, United Nations Procurement Regime, in: Peter Hilpold and August Reinisch (eds.), Völkerrecht, Europarecht und Internationales Wirtschaftsrecht, Volume 7, Frankfurt 2008, p. 95.

6 Article 3 GATT.

7 Article 2(1) GATS. Kenya has not reserved any exemptions to this rule.

8 Articles 16(1) GATS and 17(1) GATS; Neumann, note 5, p. 96. See p. 97 for the coverage of government procurement and applicability of WTO principles. 
by limiting preference of domestic firms ${ }^{9}$ and restricting local content (performance) requirements, i.e. "stipulations, imposed on investors, requiring them to meet certain specified goals with respect to their operations in [Kenya]". ${ }^{10}$ Hence, neither exists any obligation to buy or use products of Kenyan origin, nor can the government apply trade balancing requirements, nor foreign exchange restrictions. ${ }^{11}$

\section{Bilateral agreements}

International law also grants investors from Germany protection under a Bilateral Investment Agreement (BIT) between Germany and Kenya. Such BITs shall provide planning security through equal treatment and the prohibition of discriminatory measures ${ }^{12}$ or expropriations ${ }^{13}$ when investments take place. The BIT covers every kind of asset, in particular movable and immovable property, mortgages, liens, pledges, shares of companies as well as intellectual property rights. ${ }^{14}$ Moreover, investors may benefit from a Double Tax Treaty (DTT) between the two states according to which natural and legal persons of German nationality are not taxed twice in both countries. This applies to income tax, cooperation tax, capital tax and trade tax. ${ }^{15}$ The decisive criteria for a German business to profit from the DTT, however, is immediately attached to the classification of its operative modalities and physical presence in Kenya, particularly whether it constitutes a permanent establishment under the DTT. ${ }^{16}$

\section{National legal framework}

Even though the international legal framework is set out to liberalize global trade it merely provides legal cornerstones for investment conditions. Besides, said conditions do not yet

9 Article 2 refers back to the GATT.

10 United Nations Conference on Trade and Development (UNCTAD), Foreign Direct Investment and Performance Requirements: New Evidence from Selected Countries, New York 2003, p. 2. In other words, they are measures requiring investors to behave in a particular way or to achieve certain outcomes in the host country.

11 See Suzy H. Nikièma, Performance Requirements in Investment Treaties, in: International Institute for Sustainable Development, Best Practices Series, Winnipeg 2014, pp. 5 et seq.

12 Article 3(1) and (2) of the BIT.

13 Article 4(2) of the BIT, also covering actions which are tantamount to an expropriation.

14 Article 1(1) of the BIT. Intellectual property rights in particular include copyrights, patents or utility-model patents, trade-marks, trade-names, trade and business secrets, technical processes. The free transfer of payments is covered by Article 5 .

15 See Article 2(3)-(5) of the DTT, also referring to overlapping types of taxes.

16 Article 5 of the DTT. 
touch the complex issues of compliance and enforcement. Looking at national regulations thus remains essential. ${ }^{17}$

\section{Competence and procedure}

KenInvest is the primarily competent national authority for the facilitation of private investments from foreign countries. ${ }^{18}$ This, however, does not mean that all documents can be obtained there. ${ }^{19}$ The Government's plans towards a one-stop shop as in Rwanda, i.e. a single administrative body and building for foreign investors under the roof of KenInvest including a fully digitalized application and registration procedure, still need to be realized. The governmental organization assists foreign investors with information on where to apply for a specific paper, e.g. at the Nairobi City Hall to pay license fees, for obtaining the necessary licenses or for technicalities such as getting a connection to the electricity grid. In this regard "foreign investor" means a natural person who is not a citizen of Kenya, a partnership in which the controlling interest is owned by a person or persons who are not citizens of Kenya, or a company or other body corporate incorporated under the laws of a country other than Kenya. The term "investment" is to be understood in a broader sense here, i.e. generally starting a business through a company (1.) as well as committing capital to obtain additional profit (2.).

\section{Starting a business}

Starting a business first requires deciding whether to start a local company or to set up a branch office. This will depend on the type of business and the goals pursued through it. It is also noteworthy that when incorporating a local company the investor benefits from being considered a corporate citizen by paying corporate tax at a rate of $30 \%$. When setting up a branch office the company will be regarded as foreign and therefore pay $37.5 \% .{ }^{20}$ In

17 This does not only comprise foreign national legislation. The German government has put in place legal instruments to promote foreign trade under Art. 115 of the Grundgesetz (German Constitution). This is achieved through guarantees covering export businesses and direct investments in the event of the realization of a political risk. Kenya is also a member to the Multilateral Investment Guarantee Agency (MIGA) and the Africa Trade Insurance Agency (ATIA), which both insure foreign investments against non-commercial risks.

18 KenInvest is the marketing name of the Kenya Investment Authority (KIA), a statutory body established under the Investment Promotion Act No. 6 of 2004 with offices in Nairobi, Mombasa, Kisumu and Eldoret.

19 Locations for applications and formal requirements vary depending on the applicant and the project. Every project is subject to individual criteria.

20 The average tax rate in Kenya is $37.1 \%$. This value is only a general measurement of the amount of taxes and mandatory contributions payable by the business in the second year of operation, expressed as a share of commercial profits. It does not provide information about the existing sector specific incentives, duty exemptions, VAT remissions or government programs such as the Export 
any case, foreigners will need a local lawyer, not only for legal advice but for the power of representation during the implementation procedure.

Incorporating a local company is supposed to take a maximum of thirteen days for a total of thirty-one prescribed documents. It is possible to incorporate a private company limited by shares (Ltd.), a private company limited by guarantee and a private unlimited company. ${ }^{21}$ The registration process for the various forms is the same although requirements and costs do vary. The first goal is to register the company which entails obtaining the Certificate of Incorporation. This begins with the step to reserve and receive the approval for a name. ${ }^{22}$ After drafting the memorandum and articles of association it is necessary to file a request for obtaining authenticated company registration documents including a certified form containing the particulars of directors and secretaries. ${ }^{23}$ The investor then needs to pay stamp duty for all said documents, depending on the nominal capital of the company to be incorporated. ${ }^{24}$ The company registration process is concluded by handing in the franked documents ${ }^{25}$ and paying company registration fees. ${ }^{26}$ The second goal then is to obtain a business permit. This first requires registering as taxpayer by applying for and obtaining a personal identification number (company PIN) from the Kenya Revenue Authority for the purpose of tax collection. This is followed by turning in a business permit application form. ${ }^{27}$ The license fees are assessed and after payment the business permit can be obtained. The last minor steps include the employer's social security and national hospital insurance fund registration and, finally, obtaining the company seal. ${ }^{28}$

Registering a branch slightly varies from incorporating a business. The procedure shall last no longer than eleven days and includes twenty-one documents. The goal, namely obtaining a business permit, remains the same. This will first require submitting a notarized

Processing Zones Programme. See http://www.doingbusiness.org/ /media/GIAWB/Doing\%20Bus iness/Documents/Special-Reports/Paying-Taxes-2016.pdf, p. 112, accessed on 8 February 2016.

21 The first limits the members' liability to the share capital, the second limits liability to the amount they have agreed to contribute to the company's assets if it is wound up, the last means there is no limit to the members' liability. Other business entities include partnerships, limited partnerships and limited liability partnerships (LLP).

22 Companies Act 2012, Section 19 and Legal Notice No.80 of 2003 Companies Act (schedule of fees).

23 Advocates Act Section 34; Companies Act 2012 Sections 5, 9, 12, 14; Advocates Remuneration Order 2014 Article Schedule 3; Companies Act 2012 Section 201 and Certified Public Secretaries Act Section 15. Articles of association contain the company's objectives, the names and addresses of the shareholders, a statement of capital, the number of shares held by each shareholder and the signatures of all shareholders.

24 Stamp Duty Act Section 39, Stamp Duty Act Article Schedule 1.

25 Companies Act 2012 Sections 4, 5, 6, 9, 12, 15, 17, 22, 108, 178, 201.

26 Companies Act 2012 Sections 4, 5, 6, 9, 12, 15, 17, 108, 178, 201, 383; Legal Notice No.80 of 2003 Companies Act (schedule of fees).

27 Income Tax Act Sections 4, 132.

28 National Social Security Fund Act 2013 Sections 19, 20; National Hospital Insurance Fund Act; Section 16; Legal Notice No.14 of 2015-NHIF ACT; Companies Act 2015 Section 38. 
version of the memorandum of association (Gesellschaftsvertrag) and a notarized certificate of incorporation (Gründungsurkunde) of the German company, including the particulars of directors and a notice of its new location. ${ }^{29}$ After approval the company needs to pay registration fees ${ }^{30}$ and obtain the Certificate of Compliance, certifying its lawful intentions in the registration process. ${ }^{31}$ This step is, equally to the process of incorporation, followed by applying for a company PIN to register as taxpayer and, consequently, filling out the single business permit application form, paying the assessed fee for the business license ${ }^{32}$, social security and hospital insurance fund registration, and obtaining the company seal.

\section{Conditions and procedure for making an investment}

Contrary to local investors, a foreign investor must first obtain a certificate of investments before proceeding. ${ }^{33}$ Investments are only possible after having either established a local company or opened a branch office in Kenya. Procedures for consideration of the application are provided for under the first schedule to the Investment Promotion Act. According to the schedule, the whole process from filing of the application to the notice of the decision takes no more than twenty-five working days. The process starts by turning in the investment application form, a cover letter addressed to the Managing Director at KenInvest indicating the activities of the company, a project description, a simple copy of the memorandum of association, either from the country of incorporation (e.g. Germany) if the project is managed through a branch in Kenya, or from Kenya if the investor decided to incorporate a local company. ${ }^{34}$ These forms come with a proof of investment in which the amount, exceeding 100,000 US Dollars or the equivalent in any other currency, shall be stated. ${ }^{35}$ Last comes the official request for obtaining the investment certificate. ${ }^{36}$ The government will conduct an inspection of work premises, which is carried out to ascertain the existence of the company or project. KenInvest notifies the investor of the scheduled date of the visit. ${ }^{37}$

29 Companies Act 2012 Sections 366, 377; Advocates Act Section 34; Advocates Remuneration Order 2014 Article Schedule 3.

30 Companies Act 2012 Sections 365, 366, 377; Legal Notice No.80 of 2003 Companies Act (schedule of fees) (Article II).

31 Companies Act 2012 Sections 365, 366, 367.

32 Nairobi City County Finance Act 2013 Section 8.

33 Investment Promotion Act 2004 Sections 1st schedule, 2nd schedule, 3, 4, 5, 6, 7, 12, 13, 15; Legal Notice 1 of 2006-Investment Promotion Act Sections 1st schedule, 3, 5, 7, 9, 10, 11.

34 Hence, either the Certificate of Incorporation for local companies or the Certificate of Compliance for a branch of the German company respectively.

35 Investment Promotion Act 2004 Sections 3, 4; Legal Notice 1 of 2006 Investment Promotion Act Section 5.

36 Investment Promotion Act 2004 Sections 3, 4, 5, 1st schedule; Legal Notice 1 of 2006 Investment Promotion Act Sections 3, 7, 9, 1st schedule.

37 Investment Promotion Act 2004 Section 4; Legal Notice 1 of 2006 Investment Promotion Act Section 3. 
The investment and its activities related thereto must be in accordance with Kenyan law and beneficial to Kenya. The latter requires the creation of employment for Kenyans, the acquisition of new skills or technology for Kenyans and the contribution to tax or other government revenues. ${ }^{38}$

Besides fulfilling the general conditions described there exist sector specific conditions, such as those for investments in renewable energy. ${ }^{39}$ Investing in power projects of up to 40 MW requires to first file an Expression of Interest (EOI) which is then followed by a request for proposal. The proposal gets evaluated as part of a bidding process. Upon approval, the investor signs a Power Purchase Agreement (PPA) with the Kenya Power Company including a feed-in tariff policy. For solar and wind it is up to the investor to choose a certain site and sign the land leases with the respective owners. It is also possible to purchase land and obtain a title of ownership. The ownership needs to be ascertained by the Ministry of Land, Housing and Urban Development in Nairobi. The Ministry will then register the acquisition upon payment of stamp duty at a rate between 2 and $4 \%$ depending on the value. What needs to be considered in this context is that whenever identifying potential locations for an investment, Kenyan law requires an Environmental Impact Assessment which needs approval by the National Environmental Management Authority as a precondition to the issuance of the Certificate of Investment.

\section{Conclusion}

The legal environment may constitute a more crucial point to businesses than the mere calculation of potential turnover when identifying new markets in Africa. This is especially true as all African markets must be looked at individually. The question is not only whether there exist BITs or DTTs at the international level. Instead, a comprehensive analysis of national regulations, their clarity, volume and availability discloses the general readiness of a government or country to welcome and deal with foreign investors. One can also derive one more aspect from them, namely the seriousness which a government or country is trying to bind them with on a permanent basis. Any negative finding should lead to the reconsideration of a project abroad. With regard to Kenya the country's legal environment can be valued as reliable to the extent that regulations are transparent and prerequisites are quite predictable. That said, any description of procedures can only provide an overview of the most important steps that need to be taken into account when doing business there. In essence,

38 In addition to these conditions the investment should entail a transfer of technology to Kenya, an increase in foreign exchange, either through exports or import substitution, the utilization of domestic raw materials, supplies and services, the adoption of value addition in the processing of lo$\mathrm{cal}$, natural and agricultural resources, the utilization, promotion, development and implementation of information and communication technology, or any other factors that the Authority considers beneficial to Kenya.

39 Current data predicts a nationwide demand between 3,000 MW and 5,000 MW by 2017. The currently installed capacity is slightly over 2,000 MW. 
providing such a first overview is imperative. It is owed to the fact that it will always come down to the question whether an investor is able to really picture and envision the process. Awareness of formalities generally helps to reduce reluctance. Familiarizing with the regulations of an unfamiliar market provides planning security. Together with the advice of a reliable local lawyer, who should always be consulted, one can then proceed realizing the designated business endeavour. 